Journal of Engineering and Applied Sciences 5 (6): 430-434, 2010

ISSN: 1816-949X

(C) Medwell Journals, 2010

\title{
Retention of $E$. coli on Natural Pozzolan Beds
}

\author{
${ }^{1}$ Ndi Koungou Sylvere, ${ }^{1}$ Mbundapong Ndi Laura, ${ }^{2}$ Tatsadjieu Leopold, \\ ${ }^{3}$ Ali Ahmed and ${ }^{1}$ Kayem Guifo Joseph \\ ${ }^{1}$ Industrial Filtration and Water Treatment (Chem. Eng.) Group, Department of Process Engineering, \\ ENSAI, University of Ngaoundere, P.O. Box 455, Ngaoundere, Cameroon \\ ${ }^{2}$ Laboratory of Microbiology, University Institute of Technology, \\ University of Ngaoundere, P.O. Box 454, Ngaoundere, Cameroon \\ ${ }^{3}$ Department of Chemical Engineering, University Institute of Technology, \\ University of Ngaoundere, P.O. Box 454, Ngaoundere, Cameroon
}

\begin{abstract}
Micro organisms are wide spread in nature and when found in drinking water are known to be major precursors of many diseases. Their removal can be achieved through filtration in packed columns, thus reducing the amount of chemicals used for the disinfection of drinking water. Pozzolan from Djoungo (Cameroon) was tested as a potential filtration media for removing $E$. coli, the indicator of faecal contamination in ground and surface waters. Filtration experiments were carried out at room temperature $\left(24 \pm 2^{\circ} \mathrm{C}\right)$ and microbial concentration was determined by the spread plate technique. Filtration tests were performed on 2 granular size media (450 and $900 \mu \mathrm{m}$ mean size) at constant velocity $\left(0.22 \mathrm{~m} \mathrm{~h}^{-1}\right)$, at different $\mathrm{pH}(5-9)$ and ionic strengths $\left(10^{-4}-10^{-2} \mathrm{M}\right)$. The aluminium sulphate concentration of $2.5 \mathrm{mg} \mathrm{L}^{-1}$ was used while the microbial concentration was fixed at $1.46 \times 10^{2}$ cells $\mathrm{mL}^{-1}$. Results showed that the best microbial retention was obtained at $\mathrm{pH} 5$ and at a high ionic strength of $10^{-2} \mathrm{M} \mathrm{KCl}$ with coagulant dose $\left(2.5 \mathrm{mg} \mathrm{L}^{-1}\right)$. The $450 \mu \mathrm{m}$ mean diameter media presented a better efficiency compared to the coarse one.
\end{abstract}

Key words: $E$. coli, pozzolan, deep bed filtration, aluminium sulphate, water treatment, diseases

\section{INTRODUCTION}

Ground water is used as main source of drinking water in towns and rural area all over the world. Its turbidity level $(<5 \mathrm{NTU})$, low salinity $\left(<20 \mathrm{mg} \mathrm{L}^{-1}\right)$ and low amount of dissolved heavy metals in some areas allow it to be good for drinking purposes. Historically, ground water was assumed free from pathogenic microorganisms. Recent surveys indicate that a significant fraction of ground water supplies and surface water are a major source of waterborne diseases (Ndi, 2010). Many ground water sources in rural areas in Cameroon with clear natural springs have microorganism concentration exceeding WHO limits (Ndi, 2010). Their presence in water is a major threat to humanity. Micro organisms in water may result from agricultural practices like fertilization, defecation in water or disposal of human or animal waste in water and urban ills like careless disposal of house hold wastes.

These micro organisms are the major causes of diseases such as cholera, diarrhea and typhoid. Not only are these diseases expensive to treat but they are as well deadly if not diagnosed and treated on time. As the saying goes prevention is better than cure, it is better to take in potable water than curing or treating diseases caused by unsafe water. Potable water must be free from micro organisms in addition to its being tasteless, colourless and odourless. The contamination of water by micro organisms is generally expressed by the presence of $E$. coli; the indicator of faecal contamination. In remote rural areas where ground water and natural springs with elevated micro organisms' levels are the only easily accessible water sources their content should be reduced to acceptable levels.

Many methods are used to remove micro organisms from water. In water treatment plants, coagulation, sedimentation, filtration and disinfection steps help to reduce microbial charge as well as other contaminants in water. The last step is the most efficient in the reduction of microorganisms but need the use of high amounts of chemicals (Rooklidge et al., 2002). The efficiency of the disinfection step can be increased by increasing the efficiency of the previous steps (coagulation,

Corresponding Author: Ndi Koungou Sylvere, Industrial Filtration and Water Treatment (Chem. Eng.) Group, Department of Process Engineering, ENSAI, University of Ngaoundere, P.O.Box 455, Ngaoundere, Cameroon 
sedimentation and filtration). Granular filtration has been found to be very effective for the retention of protozoan parasites such as Giardia and Cryptosporidium, difficult to eliminate during disinfection steps (Stevenson, 2003). As it is the last step of elimination of suspended particles in classical water treatment units, it should also be able to reduce considerably the amount of microorganisms from water. Many studies have shown that microorganisms could be attached on granular particles under favourable or unfavourable conditions, related to the surface chemistry of the grain particle and the bio colloid (Hann and O'Melia, 2004). Therefore coating sand with aluminium or ferric oxidesexhibited higher retention efficiency than natural sand (Bolster, 2001). Unlike coated sand, pozzolan, a natural volcanic material contains aluminium and ferric oxides on their surfaces (Messi et al., 1994; Ndi et al., 2008). It has been found to be more efficient than granular sand in the removal of clay colloidal particles (Ndi et al., 2006) and in this study its efficiency is evaluated on E. coli (a biocolloid) under various physicochemical conditions $(\mathrm{pH}$, ionic strength, aluminum sulphate concentration and collector size).

\section{MATERIALS AND METHODS}

Biological material: Lyophilized $E$. coli of the $\mathrm{k}_{12}$ batch was obtained from the Microbiology laboratory of IUTENSAI. A pintchof lyophilised $E$. coli $\mathrm{K} 12$ strain was put in a sterilised test tube containing $1 \mathrm{~mL}$ of physiological solution and agitated using an electrical agitator until the bacteria got completely dispersed in the solution. About $0.1 \mathrm{~mL}$ of the $E$. coli strain was then inoculated on preprepared EMB (Eosine Methylene Blue) culture medium. After $24 \mathrm{~h}$ of incubation in an incubator at $37^{\circ} \mathrm{C}$, growth of colonies was observed. An E. coli colony was obtained from the EMB medium and cultured in $150 \mathrm{~mL}$ of TSB (Tryticase Soya Broth) and incubated for $24 \mathrm{~h}$ in an incubator at $37^{\circ} \mathrm{C}$. The medium became cloudier than before, indicating that growth of $E$. coli had occurred. The bacteria suspension in the TSB medium was then centrifuged in a Hereuse centrifuge at a rate of $6000 \mathrm{rpm}$ and rinsed 3 times. This was to purify the bacteria strain by separating the bacteria from the TSB medium.

The pure bacteria strain was then suspended in physiological solution to avoid cell hemolysis and to maintain the physiological state of the cells. The bacteria in the suspension were then kept in a Memmert refrigirator at $4-10^{\circ} \mathrm{C}$ to avoid aging of the cells and to minimize cell multiplication. All other reagents used in the present study were of analytical grade.

Granular material: Granular material was prepared from pozzolan excavated from Djoungo in the Littoral region of
Cameroon. The material was crushed, sieved and washed several times to obtain a final turbidity level $<0.5 \mathrm{NTU}$. The resulting material had three granular sizes: $400-500$, $630-800$ and $800-1000 \mu \mathrm{m}$. It was dried at $105^{\circ} \mathrm{C}$ in an oven (Heraeus, Germany), allowed to cool down in adesiccator at room temperature and sealed in sterile plastic bags. It was then used without further purification. Recent researchers on this material using SEM/microprobe, revealed the presence of different oxides mainly iron oxides corresponding to goethite and hematite and aluminium oxide (gibbsite) and titanium dioxide.

The granular pozzolans of Djoungo has an isoelectric point (iep) located around $\mathrm{pH} \mathrm{3}$, with a negative surface charge within the range of experiments $(<-30 \mathrm{mV})$ (Stevenson, 2003).

Filtration experiments: The filtration plant consists of two supply tanks, stirred with a magnetic stirrer as shown in Fig. 1. A membrane pump allows the transfer of the fluid through the glass filtration column. The internal diameter of the column is $24 \mathrm{~mm}$. Prior to use, tubes and column were cleaned thoroughly with tap water and soap. They were then disinfected with chlorinated water at $25 \%$ dilution and thorough rinsing with abundant distilled sterilised water followed.

After packing column with the granular material, distilled water, of fixed $\mathrm{pH}$ and ionic strength, was used to flush the bed for $>30 \mathrm{~min}$ in an upflow mode. Before the retention experiments, the suspensions are coagulated by gently introducing with a syringe, the exact amount of commercial aluminumsulphate $\left(1 \mathrm{~g} \mathrm{~L}^{-1}\right)$ in the suspension, maintained under agitation. This mixing would prevent sedimentation in the source water tank. The coagulated suspension was then introduced into the column in an upward flow mode. At the exit of the column the filtrate was collected as a function of time and analyzed by cell enumeration.

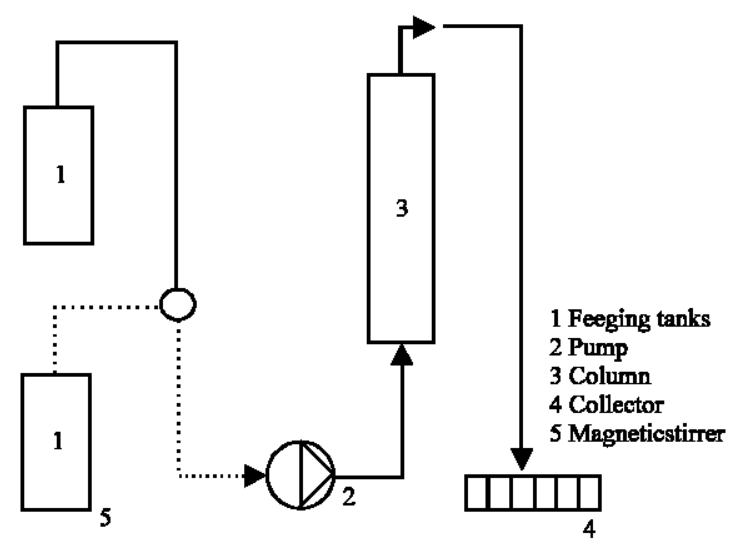

Fig. 1: Schematic diagram of apparatus used 
Cell enumeration: Suspended E. coli in the filtrate obtained was enumerated by spread plate technique. Appropriate sample dilutions (for feed of initial bacterial concentration of $1.46 \times 10^{2}$ cells $\mathrm{mL}^{-1}$ of feed) were obtained by serial dilutions in physiological solution. The plating media were MacConkey and Eosin Methylene Blue Agar.

For feed with an initial bacteria concentration of $1.46 \times 10^{2}$ cells $\mathrm{mL}^{-1}$, since less cells were suspected in the filtrate, cell enumeration proceeded by membrane filtration using Whatman sterile membrane filters or nylon plain membrane filters with pore size equal to $0.45 \mu \mathrm{m}$. Membrane filtration was followed by inoculation on MacConkey or Eosin Methylene Blue Agar in Petri dishes. They were further incubated at $37^{\circ} \mathrm{C}$ for $24-48 \mathrm{~h}$ which was time enough to allow for growth.

\section{RESULTS AND DISCUSSION}

Effect of pH: The results of the influence of $\mathrm{pH}$ on the retention of $E$. coli on pozzolan grains are shown in Fig. 2. Increasing the $\mathrm{pH}$ did not change notably the overall amount of $E$. coli retained in the pozzolan bed at low ionic strength $\left(10^{-4} \mathrm{M} \mathrm{Kcl}\right)$ and at different $\mathrm{pH}$ $\left(5,7\right.$ and 9). The $\log (C) / \log \left(C_{0}\right)$ is within the range of $0.6-0.8(<1)$ and is almost constant with the reduced volume of filtrate collected. As shown, the retention is observed within the first $5 \mathrm{~min}$ and does not change with the reduced volume of filtrate. As the ratio $\log (\mathrm{C}) / \log \left(\mathrm{C}_{0}\right)$ is $<1$, it can be deduced that in these conditions, an amount of $E$. coli is retained in the bed.

With low ionic strength cell-cell and cell-collector interactions are reduced (Elimelech, 1991). So, cell aggregation in the suspension or in the bed is not the main mechanism involved (Hann and O'Melia, 2004). Increasing the $\mathrm{pH}$ from 5-9, should have change the

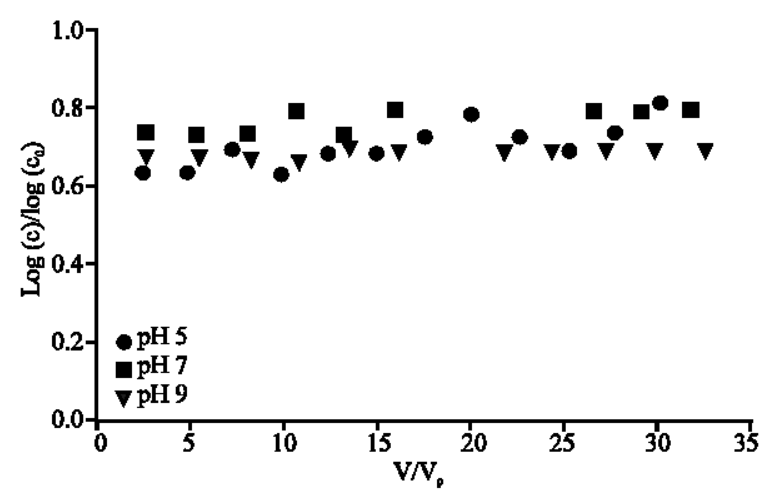

Fig. 2: $\log (\mathrm{C}) / \log \left(\mathrm{C}_{0}\right)$ versus $\mathrm{V} / \mathrm{Vpat} \mathrm{pH} 5,7$, retention on granular pozzolan $(400-500 \mu \mathrm{m})$, equivalent ionic strength 9, 10-4 M KCL surface charge on pozzolan grains and on $E$. coli cells. But as shown by the results changing the $\mathrm{pH}$ did not result in a drastic change in the overall amount of $E$. coli retained in the pozzolan bed. As the surface charge of pozzolan grains and $E$. coli at low ionic strength and at $\mathrm{pH}>5$ is negative $(<-30 \mathrm{mV}$ ) (Hann and O'Melia, 2004), the interaction between those particles can be assumed to be unfavorable (Puls et al., 1993). In these conditions, the observed retention could be explained by the cell-grain interactions under unfavorable retention conditions which has been attributed to the surface charge heterogeneity of pozzolan and the roughness of the collector (Elimelech, 1991; Puls et al., 1993).

Effectof ionic strength: Figure 3 shows theinfluence of the ionic strength on the retention of $E$. coli at $\mathrm{pH} 5$. No significant difference was observed at $10^{-4}$ and $10^{-3} \mathrm{M}$ $\mathrm{KCL}$ while with ionic strength equal to $10^{-2} \mathrm{M} \mathrm{KCL}$ the amount of $E$. coli retained within the bed was greater than the previous cases. At $10^{-4} \mathrm{M} \mathrm{KCl}$ and $10^{-3} \mathrm{KCl}$, the ionic cloud around the particle is very large, compared to $10^{-2}$ $\mathrm{M} \mathrm{KCL}$, thus at high ionic strength collision efficiency of cell-cell and cell-collector increases as it reduces cellcelland cell-collector separation distance. This trend is coherent with what have been found by other on the influence of the ionic strength on the retention efficiency (Bai and Tien, 1999).

Effect of aluminium dose and cell concentration: Figure 4 shown the results for the retention of E. coli at different concentrations and different amount of aluminumsulphateused. Without any coagulant used, no significant retention was observed for both 146 and 1460 UI $\mathrm{mL}^{-1}$ amount of $E$. coli in the suspension. As shown here as earlier, without any coagulation, less amount of $E$. coli is retained in the bed while using aluminium

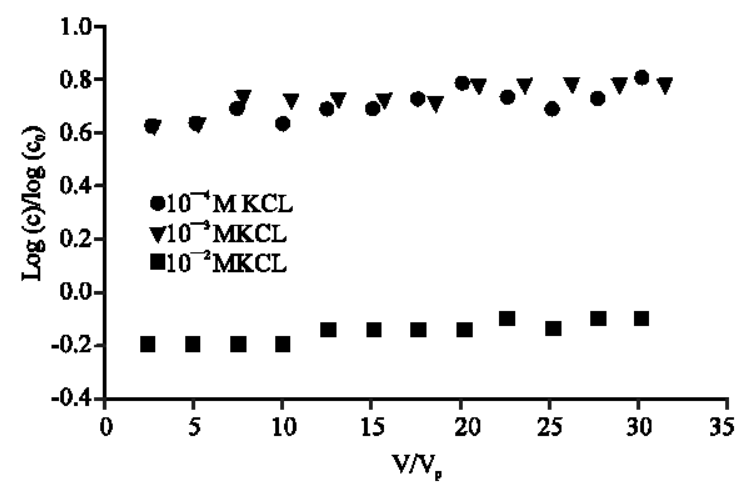

Fig. 3: $\log (C) / \log \left(\mathrm{C}_{0}\right)$ versus V/Vpat equivalent ionic strength of 10-4, 10-3 and 10-2 MKCL, retention on granular pozzolan $(400-500 \mu \mathrm{m})$ at fixed $\mathrm{pH} 5$ 


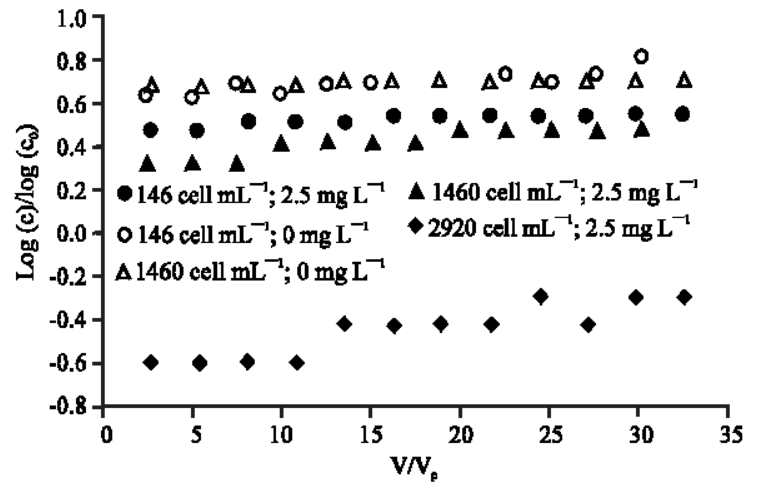

Fig. 4: $\log (\mathrm{C}) / \log \left(\mathrm{C}_{0}\right)$ versus $\mathrm{V} /$ Vpat different aluminum dose

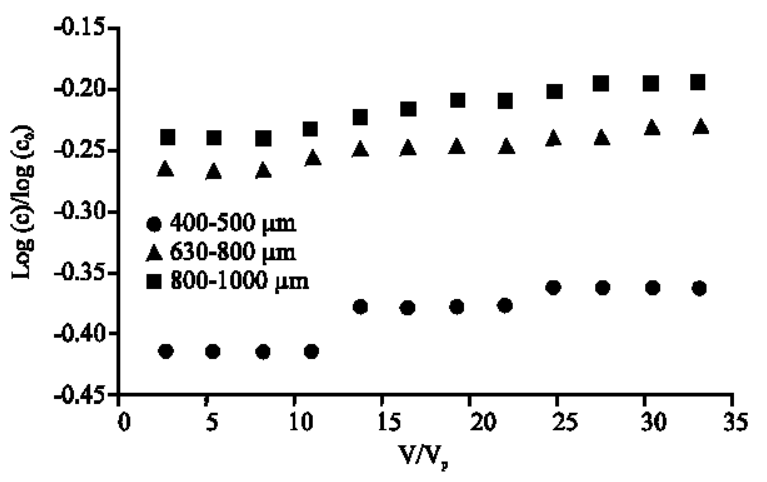

Fig. 5: $\log (\mathrm{C}) / \log (\mathrm{C} 0)$ versus $V /$ Vpat different collector size

sulphate improved its retention. Increasing the amount of particles up to 2920 cell $\mathrm{mL}^{-1}$ using the same amount of coagulant as in the previous experiments gave better retention of $E$. coli but the retention mode was found to be less stable as the release of $E$. coli cells was observed with the reduced filtrate volume.

The amount of coagulant used $\left(2.5 \mathrm{mg} \mathrm{L}^{-1}\right)$ corresponds to the highest concentration of aluminum sulphate which could be used for the removal of clay particles in a suspension of 60 NTU (Kretzschmar et al., 1994). Therefore, for the retention of a microorganisms found in a water of the same type, using this maximum concentration of aluminum sulphate could give us an indication on the capture mechanism involved.

The best retention was observed for the more concentrated suspension. This behavior could be explained by the concentration of the suspensions used. For dilute suspensionscollision efficiencies between particles is low, indicating that the aggregates generated from those diluted suspension would have low dimensions. For more concentrated solutions, as the coagulation is effective on those particles, the aggregates size would be greater than in the first case (Puls et al.,
1993). Thus, cell-cell interactions where very pronounced at $2.5 \mathrm{mg} \mathrm{L}^{-1}$ of aluminum sulphate used. So, the retention of $E$. coli suspensions at low concentration will be less efficient than the retention of a more concentrated solution in pozzolan granular bed if aluminum sulphate is used as a coagulant.

Effect of media size: The influence of collector size is shown in Fig. 5. Retention experiments where carried out with aluminum sulfate $\left(2.5 \mathrm{mg} \mathrm{L}^{-1}\right)$ at $10^{-3} \mathrm{M} \mathrm{KCl}, \mathrm{pH} 5$ and at various pozzolan grain sizes. As the size of the collector increases, the overall retention of $E$. coli cells in pozzolan beds decreases. So, compared with other collector size, greater retention was found with pozzolan grains of $400-500 \mu \mathrm{m}$. After $10 \mathrm{~V} / \mathrm{Vp}$, the released of $E$. col $i$ cells in pozzolan bed $(400-500 \mu \mathrm{m})$ is higher than in the other beds.

About 2 mechanisms may explain the capture observed in the bed. As the size of the collector size is reduced, the hydraulic radius is also reduced and the collision efficiency between cell-cell and cell-collector increases in the bed (Hann and O'Melia, 2004). Also, reducing the size of the particles increases the screening effect of the bed. So, coupling aggregation and screening effect of the bed would increase the amount of $E$. coli retained in the bed. In this condition, more cells may be retained in the bed and with hydraulic flow thry may be detached as found in this present case (Hann and O'Melia, 2004).

\section{CONCLUSION}

Retention of low charge of $E$. coli in water through granular pozzolan bedscan be achieved without using aluminum sulphate as a coagulant at different $\mathrm{pH}$ (Hann and O'Melia, 2004; Bolster, 2001; Messi et al., 1994; Ndi et al., 2006, 2008). Using aluminum sulfate increases the observed retention and has been found to be very effective on pozzolan granular size of $400-500 \mu \mathrm{m}$. Sousing pozzolan grains for filtration process may reduce the overall amount of chemicals use for disinfection.

\section{ACKNOWLEDGEMENTS}

The researchers would like to thank the University of Ngaoundere, CIMENCAM of Douala for providing the pozzolan material and the Colonel NDI and the Bingangoye Family in Gabon for funding this research.

\section{REFERENCES}

Bai, R. and C. Tien, 1999. Particle deposition under unfavourable surface interactions. J. Colloid Interface Sci., pp: 488-499. 
Bolster, C.H., 2001. Effect of surface coatings, grain size and ionic strength on the maximum attainable coverage of bacteria on sand surfaces. J. Contamin. Hydrologie, 50: 287-305.

Elimelech, M., 1991. Kinetics of capture of colloidal particles in packed beds under attractive double layer interactions. J. Colloid Interface Sci., 46: 337-352.

Hann, M. and C.R. O'Melia, 2004. Deposition and reentrainment of brownian particles in porous media under unfavorable chemical conditions: Some concepts and applications. Environ. Sci. Technol., 38: $210-220$.

Kretzschmar, R., W. P. Robarge and A. Amoozegar, 1994. Filter efficiency of tree saprolites for natural clay and iron oxide colloids. Environ. Sci. Technol., 28: 1907-1915.

Messi, A., J. Perra, C. Bitjokaand and J. Tusset, 1994. Study and evaluation of pozzolanic activity of pozzolans djoungo (Cameroon). Ann. Fac. Sci. H. S. I. Chem. Earth Sci., pp: 133-144.

Ndi, K.S., 2010. Quality of ground water in Northern part of Cameroon. Water for Life, Ngaoundere, Annual Report.
Ndi, K.S., D. Dihang, P. Aimar and G.J. Kayem, 2008. Retention of bentonite in granular natural pozzolan: Implications for water filtration. Separat. Sci. Technol., 2008: 1621-1631.

Ndi, K.S., D. Dihang, P. Mpouli, P. Aimar and G.J. Kayem, 2006. Evaluation of natural pozzolan beds for the filtration of higher turbidity surface water. Proceedings of the 2nd European Conference on Filtration and Separation, (ECFS'06), New Filtration and Separation Applications, Compiegne, France, pp: 321-327.

Puls, R.W., J.P. Cynthia and A.C. Donald, 1993. Surface chemical effects on colloid stability and transport through natural porous media. Colloids Surfaces aPhysicochem. Eng. Aspects, 73: 287-300.

Rooklidge, S.J., L.H. Jr Ketchum and P.C. Burns, 2002. Clay removal in bsaltic and limestone horizontal roughing filters. Adv. Environ. Res., 7: 231-237.

Stevenson, D.G., 2003. A review of current and developing potable water treatment processes. Proc. Inst. Mech. Eng. Part E-J. Process Mech. Eng., 217: 11-23. 